\title{
Salt Tolerance of Xylocarpus mekongensis Pierre: Survival and Growth of Seedlings, Nutrients and Carbon Distribution in Seedling Parts
}

\author{
Sanjoy Saha1, Mahmood Hossain ${ }^{*}{ }^{\circledR}$, Md. Sajib Hossain², Mohammad Raqibul Hasan Siddique ${ }^{2}$, \\ S. M. Rubaiot Abdullah², Chameli Saha² \\ ${ }^{1}$ Institute for Integrated Studies on the Sundarbans and Coastal Ecosystems (IISSCE), Khulna University, Khulna, Bangladesh \\ ${ }^{2}$ Forestry and Wood Technology Discipline, Khulna University, Khulna, Bangladesh \\ Email: sanjoyfwt@yahoo.com, `mahmoodhossain@hotmail.com, sajib_fwt@yahoo.com,rqibulhasan_fwt@yahoo.com, \\ rubaiot@yahoo.com,chamelifwt@gmail.com
}

How to cite this paper: Saha, S., Hossain, M., Hossain, Md. S., Siddique, M. R. H., Abdullah, S. M. R., \& Saha, C. (2020). Salt Tolerance of Xylocarpus mekongensis Pierre: Survival and Growth of Seedlings, Nutrients and Carbon Distribution in Seedling Parts. Open Journal of Forestry, 10, 293-306. https://doi.org/10.4236/ojf.2020.103019

Received: April 13, 2020

Accepted: May 17, 2020

Published: May 20, 2020

Copyright (c) 2020 by author(s) and Scientific Research Publishing Inc. This work is licensed under the Creative Commons Attribution International License (CC BY 4.0).

http://creativecommons.org/licenses/by/4.0/

\begin{abstract}
Xylocarpus mekongensis Pierre is the important tree species of the Sundarbans. The present study was conducted to evaluate the effect of salinity on the survival and growth of $X$. mekongensis seedlings. The distributional patterns of nitrogen, phosphorus, potassium, sodium, and carbon in seedling parts were also examined in relation to salinity. Comparatively higher survival (95\%) of seedlings was observed at non-saline to slightly saline conditions (0 5 PSU) and it was decreased to $78 \%$ at 35 PSU salinity. The relative growth rate (RGR) was higher at non-saline to slightly saline (0 to $5 \mathrm{PSU}$ ) conditions compared to higher salinity. Nutrients, sodium, and carbon concentration are found to vary significantly $(p<0.05)$ among the parts of seedlings. Comparatively $(p<0.05)$ highest concentration of nitrogen $(20$ to $34 \mathrm{mg} / \mathrm{g}$ ), phosphorus $(0.50$ to $0.75 \mathrm{mg} / \mathrm{g}$ ), potassium ( 9 to $27 \mathrm{mg} / \mathrm{g}$ ) and sodium (7 to $36 \mathrm{mg} / \mathrm{g}$ ) were found in leaves, while the highest concentration of carbon ( $42 \%$ to $45 \%$ ) was detected in the stem. However, nitrogen, potassium, and carbon concentration in different parts of seedlings showed significant $(p<0.05)$ negative correlations with salinity levels. It can be concluded that $X$. mekongensis has the capacity to tolerate higher saline condition but they grow well in non-saline to less saline conditions.
\end{abstract}

\section{Keywords}

Growth, Mangroves, Nutrients, Salinity, Survival, Xylocarpus mekongensis 


\section{Introduction}

Mangroves are a taxonomically heterogeneous association of salt-tolerant trees and shrubs growing along the tropical and subtropical worm coastlines (Downton, 1982). The salinity is a special characteristic of the mangrove habitats. This salinity has influences on the seed germination, sprouting of propagules, seedling growth and survival of mangroves plant species (Downton, 1982; Elumalai \& Manikandan, 2013; Lovelock et al., 2004; Mahmood et al., 2014a; Naidoo, 2006). The higher amount of uptake and accumulation of $\mathrm{Na}^{+}$and $\mathrm{Cl}^{-}$in plant tissues have a negative influence on plant growth and development by influencing the nutrient uptake mechanisms. High salinity level reduces nutrient uptake and accumulation (Fernández-García et al., 2004); affects the nutrient partitioning within the parts of the plant (Mahmood et al., 2014a). Moreover, higher salinity causes the physiological inactivation of a given nutrient that results in increasing demand of that particular nutrients by the plants (Grattan \& Grieve, 1999) and imposes ion toxicity and disturbance in nutrient balance (Khan et al., 2000; Patel et al., 2010). In most of the cases, an increased level of salinity leads to increase $\mathrm{Na}^{+}$and $\mathrm{Cl}^{-}$ions in plant tissue and results in decreased concentration of N, P, $\mathrm{K}^{+}$, and Ca2 ${ }^{+}$(Karimi et al., 2005; Tuna et al., 2007; Navarro et al., 2008).

The level of salinity tolerances is found to vary with mangrove species and this level of tolerance is the key factor for the survival and growth of a particular mangrove species (Nandy et al., 2007; Mahmood et al., 2014b). Studies have shown that the growth of some mangrove species was higher at lower salinities (e.g. Chen \& Ye, 2014 for Excoecaria agallocha; Mahmood et al., 2014a for Heritiera fomes). Some other studies observed higher growth at moderate salinities (e.g. Hoppe-Speer et al., 2011 for Rhizophora mucronata; Patel et al., 2010 for Ceriops tagal; Smith \& Snedaker, 1995 for Rhizophora mangle). However, up to a certain limit of further increases in salinity inevitably decreased the growth of mangrove plants (Chen \& Ye, 2014; Mahmood et al., 2014b). The uptake rate of nutrients and their distribution pattern in plant's parts are found to vary with mangrove species in a particular salinity (Musyimi et al., 2007).

Xylocarpus mekongensis is the most valuable timber species of the Sundarbans mangrove forest of Bangladesh and found to grow well in moderate saline areas. This species occurs in association with Heritiera fomes, Avicennia officinalis, or Bruguiera gymnorrhiza (Mahmood, 2015). Xylocarpus mekongensis occupies $3.09 \%$ of vegetative cover but this coverage is depleting at the rate of $0.10 \%$ per year (Iftekhar \& Saenger, 2008). This species showed higher germination (85\%) in less saline condition than high saline condition (57\%) (Mahmood et al., 2014b). With time, the increasing salinity pattern in the Sundarbans is clear due to the reduction of freshwater flow from upstream, change in rainfall pattern and sea-level rise (Gopal \& Chauhan, 2006). However, about 30\% of the seedling density in the Sundarbans mangrove forest of Bangladesh has been declined within 13 years from 1997 to 2010 (Mahmood et al., 2017). It is hypothesized that seedling density in the Sundarbans may be controlled by the salinity. There- 
fore, a study is needed to investigate the effect of salinity on the survival and growth of $X$. mekongensis seedling being a major tree species of the Sundarbans. The present study aimed to look at the effect of salinity on survival, growth, nutrients $(\mathrm{N}, \mathrm{P}$, and $\mathrm{K})$, sodium $(\mathrm{Na})$ and carbon distribution pattern in different parts of $X$. mekongensis seedling.

\section{Materials and Methods}

\subsection{Site Description, Seed Collection and Seedling Raising}

The mature fruits were plucked from the healthy $X$. mekongensis trees from Harbaria (22.18666 N, 89.39340 E) under the Chandpai range of the Sundarbans, Bangladesh during June and July in 20118. The fruit collection site belongs to the moderate saline zone (10 - 25 PSU) and is dominated by $X$. mekongensis (Siddiqi, 2001). The site is nearly $300 \mathrm{~m}$ away from the canal bank with an average elevation of 1.4 to $2.1 \mathrm{~m}$ above the mean sea level. The site is mainly silty clay loam or alluvium and is mostly neutral to mildly alkaline in nature (Siddiqi, 2001). As the area is relatively high, it is expected to inundate by the tidal water only during the full moon. Climate is extremely seasonal and $87 \%$ of the annual precipitation $(1500 \mathrm{~mm})$ occurs between May and October keeping the other months relatively dry with little to no precipitation (Siddiqi, 2001). Maximum temperatures range from $18^{\circ} \mathrm{C}$ to $35^{\circ} \mathrm{C}$ in summer and minimum temperatures range from $12^{\circ} \mathrm{C}$ to $29^{\circ} \mathrm{C}$ in winter.

The collected seeds were sorted manually to discard the damaged/defective ones. Seeds were sown on in a germination bed $(1 \times 5 \mathrm{~m})$ of the coarse sand layer of $30 \mathrm{~cm}$ at the non-saline condition. Watering was done every day early in the morning and late afternoon to compensate for the evaporative loss. The seedlings were raised in the nursery bed for six months.

\subsection{Experiment Setup}

Six-month-old seedlings were planted in perforated PET bottles $(9 \mathrm{~cm}$ in diameter and $20 \mathrm{~cm}$ in height) filled with coarse sand (Figure 1) and a total of 96 seedlings were planted in pet bottles. Collar diameter, height and green biomass of each seedling including leaves, stem, and roots were measured and recorded. Ten seedlings were taken to the laboratory and oven-dried at $80^{\circ} \mathrm{C}$ for 4 days to calculate the green to oven-dry weight conversion ratio. Twelve seedlings with pet bottles were placed in a plastic box $(46 \mathrm{~cm} \times 30 \mathrm{~cm} \times 24 \mathrm{~cm})$ and thus 8 boxes were prepared.

Eight salinity treatments (0 - 35 PSU at 5 PSU intervals) were used to see the response of seedlings in hydroponic media with a modified Hogland solution. Here, distilled water was used for 0 PSU treatment level and the other seven levels of salt solution $(5,10,15,20,25,30$ and 35 PSU) were prepared by using crude sea salt (unrefined sea salt) containing all the chemical constituents of seawater. The modified Hogland solution (Table 1) was adopted to avoid further contamination of $\mathrm{Na}^{+}$and $\mathrm{Cl}^{-}$from the original solution (Mahmood et al., 2014a). 
The salinity level of the experiment was increased gradually at the rate of 2.5 PSU/week by following the method of Siddique et al. (2017) to cope with the seedlings with the sudden shock of increased salinity. The layout of the treatment has been presented in Figure 2. The nutrient solution was replaced weekly and salinity levels were checked regularly by using a portable hand salinity refractometer (RHS-4/ATC). Each treatment was kept for 25 weeks in a glasshouse under natural temperature $\left(32^{\circ} \mathrm{C}\right.$ to $\left.35^{\circ} \mathrm{C}\right)$ and light. The $\mathrm{pH}$ of the nutrient medium was maintained at $7.5-8$ for all the treatments.

Table 1. Composition of the modified modified Hogland nutrient solution used in experiment.

\begin{tabular}{ccc}
\hline Salt & For Stock solution $\left(\mathrm{g} \cdot \mathbf{l}^{-1}\right)$ & To use $\left(\mathrm{ml} \cdot \mathbf{l}^{-1}\right)$ \\
\hline $\mathrm{NH}_{4} \mathrm{H}_{2} \mathrm{PO}_{4}$ & 115.00 & 1.00 \\
$\mathrm{KNO}_{3}$ & 101.11 & 6.00 \\
$\mathrm{Ca}\left(\mathrm{NO}_{3}\right)_{2} \cdot 4 \mathrm{H}_{2} \mathrm{O}$ & 236.20 & 4.00 \\
$\mathrm{MgSO}_{4} \cdot 7 \mathrm{H}_{2} \mathrm{O}$ & 246.50 & 2.00 \\
$\mathrm{MnSO}_{4} \cdot \mathrm{H}_{2} \mathrm{O}$ & 0.57 & 1.00 \\
$\mathrm{H}_{3} \mathrm{BOP}_{4}$ & 2.86 & 1.00 \\
$\mathrm{CuSO}_{4} \cdot 5 \mathrm{H}_{2} \mathrm{O}$ & 0.08 & 1.00 \\
$\left(\mathrm{NH}_{4}\right)_{6} \mathrm{Mo}_{7} \cdot 4 \mathrm{H}_{2} \mathrm{O}$ & 0.02 & 1.00 \\
$\mathrm{ZnSO}_{4} \cdot 5 \mathrm{H}_{2} \mathrm{O}$ & 0.22 & 1.00 \\
$\mathrm{C}_{6} \mathrm{H}_{8} \mathrm{O}_{7} \mathrm{FeNH}_{3}$ & 5.00 & 1.00 \\
\hline
\end{tabular}
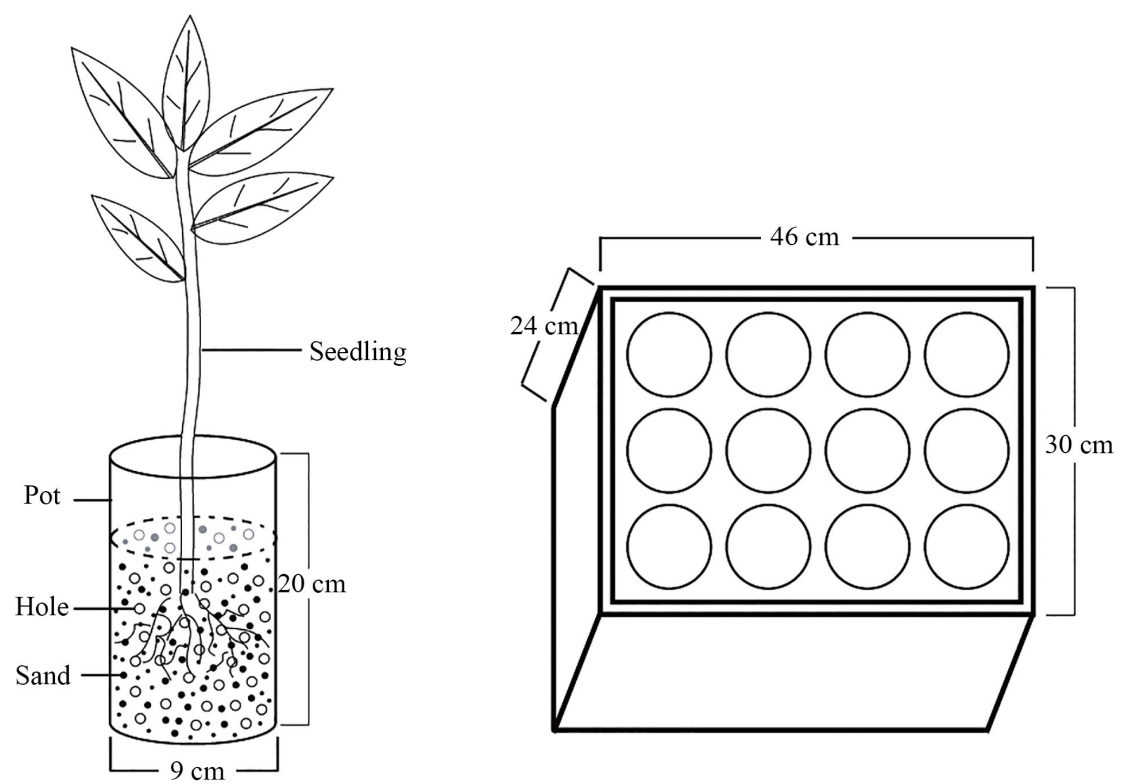

Figure 1. Bottle and box preparation for growth experiment. 


\begin{tabular}{|c|c|c|c|c|c|c|c|c|c|}
\hline & & \multicolumn{8}{|c|}{ Salinity (PSU) } \\
\hline & & 0 & 5 & 10 & 15 & 20 & 25 & 30 & 35 \\
\hline & 1 & 0 & 0 & 0 & 0 & 0 & 0 & 0 & 0 \\
\hline & 2 &. & 2.5 & 2.5 & 2.5 & 2.5 & 2.5 & 2.5 & 2.5 \\
\hline & 3 & . & 5 & 5 & 5 & 5 & 5 & 5 & 5 \\
\hline & 4 & . & . & 7.5 & 7.5 & 7.5 & 7.5 & 7.5 & 7.5 \\
\hline & 5 & . & . & 10 & 10 & 10 & 10 & 10 & 10 \\
\hline & 6 & . & . & . & 12.5 & 12.5 & 12.5 & 12.5 & 12.5 \\
\hline & 7 & . & . & . & 15 & 15 & 15 & 15 & 15 \\
\hline & 8 & . & . & . & . & 17.5 & 17.5 & 17.5 & 17.5 \\
\hline & 9 & . & . & . & . & 20 & 20 & 20 & 20 \\
\hline \multirow[t]{10}{*}{ Week } & 10 & . & . & . & . & . & 22.5 & 22.5 & 22.5 \\
\hline & 11 & . & . & . & . & . & 25 & 25 & 25 \\
\hline & 12 & . & . & . & . & . & . & 27.5 & 27.5 \\
\hline & 13 & . & . & . & . & . & . & 30 & 30 \\
\hline & 14 & . & . & . & . & . & $\cdot$ & . & 32.5 \\
\hline & 15 & . & . & . & . & . & . & . & 35 \\
\hline & . & $\cdot$ & . & . & . & . & $\cdot$ & . & $\cdot$ \\
\hline & $\cdot$ & $\cdot$ & . & $\cdot$ & . & . & $\cdot$ & . & $\cdot$ \\
\hline & . & $\cdot$ & $\cdot$ & $\cdot$ & $\cdot$ & $\cdot$ & $\cdot$ & . & $\cdot$ \\
\hline & 25 & 0 & 5 & 10 & 15 & 20 & 25 & 30 & 35 \\
\hline
\end{tabular}

Figure 2. Temporal diagram of the gradual change in salinity.

\subsection{Survival and Growth of Seedlings}

The number of survived seedlings in each salinity treatment was counted at the end of the experiment and the survival percentage was calculated. At the end of the experiment, all the seedlings were harvested and their biomass was measured according to salinity treatments. The relative growth rate (RGR, $\mathrm{gd}^{-1}$ ) was calculated according to Siddique et al. (2017):

$$
\mathrm{RGR}=\left(\ln B_{t}-\ln B_{0}\right) /\left(t_{t}-t_{0}\right)
$$

where $B_{t}$ is the final dry biomass of the seedling measures and $B_{0}$ is the initial dry biomass of the seedling estimated from the fresh to oven-dry weight conversion ratio.

\subsection{Nutrients (N, P and K), Sodium and Carbon in Seedling Parts}

Sub-samples (100 g) of seedling parts (leaf, bark, stem, and root) were randomly collected from the harvested seedlings of each treatment and oven-dried at $80^{\circ} \mathrm{C}$ for 4 days except leaves, which was oven-dried at $60^{\circ} \mathrm{C}$ for 5 days. The oven-dried samples were crushed and sieved to $2 \mathrm{~mm}$ particle size after ensuring homogeneity. The sieved sample was acid digested according to Allen (1989). Nitrogen and phosphorus in the sample extract were measured according to Baethgen \& Alley (1989) and Olsen \& Sommers (1982) respectively. Potassium and sodium 
in the sample extract were measured by Flame photometer (PFP7, Jenway LTD, England). Loss on ignition method was followed to estimate the carbon concentrations in samples (Allen, 1989).

\subsection{Statistical Analysis}

The survival percentage value of each treatment was transformed to arcsine and one-way analysis of variance (ANOVA) followed by Duncan Multiple Range Test (DMRT) was conducted to compare the survival percentages among the salinity treatments. Biomass increment in different salinity treatments was also compared by one-way ANOVA followed by DMRT. The ANOVA analysis was conducted using SAS 6.12 statistical software. Correlation analysis among salinity and different parameters (i.e. survival percentages, relative growth rate (RGR) and nutrients, sodium, and carbon in seedling parts) were performed by using MS Excel.

\section{Results}

\subsection{Survival Seedlings}

The highest survival of seedlings (95\% - 92\%) was found at non-saline (0 PSU) to slightly saline treatments (10 PSU) and lowest lower survival (78\%) was observed at the highest saline treatment of 35 PSU (Figure 3(a)). The survival of seedling showed significantly $(p<0.05)$ strong negative correlation $(\mathrm{r}=-0.93)$.

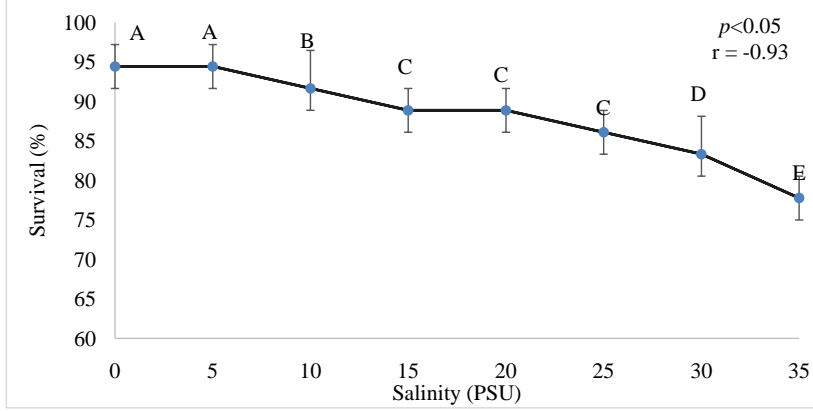

(a)

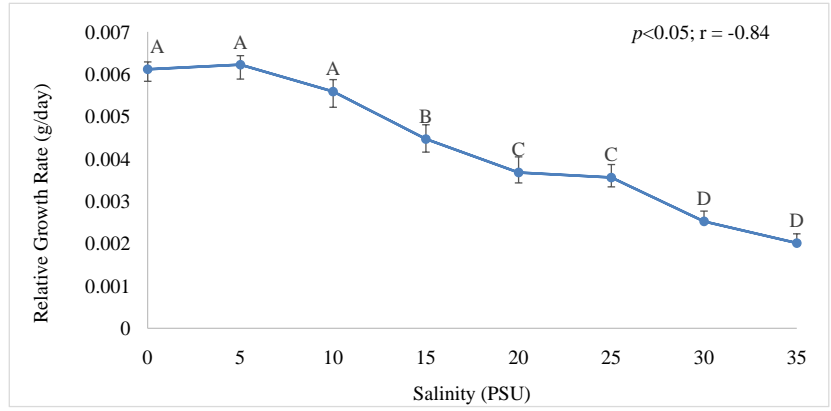

(b)

Figure 3. Salinity influence on (a) survival and (b) growth of Xylocarpus mekongensis seedlings. The mean with a similar alphabet has no significant ( $p>0.05)$ difference according to one-way ANOVA followed by DMRT. 


\subsection{Growth of Seedlings}

Seedlings showed highest relative growth $\left(0.0062 \mathrm{~g} \cdot \mathrm{d}^{-1}\right)$ rate in non-saline (0 PSU) to slightly saline condition (5 PSU) treatments, but this growth rate declined with the increasing salinity treatments. The RGR showed a significant ( $p$ $<0.05)$ negative correlation $(r=-0.84)$ with saline treatments (Figure $3(b)$ ).

\subsection{Nutrients (N, P and K), Sodium, and Carbon in Seedling Parts}

Significant $(p<0.05)$ difference was observed in nitrogen, phosphorus, potassium, sodium, and carbon concentration of different parts of seedlings at different salinity treatments with the exception of nitrogen concentration in bark and stem (Table 2).

Considering all the treatments, leaves contained comparatively higher concentration of nitrogen $\left(20-34 \mathrm{mg} \cdot \mathrm{g}^{-1}\right)$, phosphorus $\left(0.50-0.75 \mathrm{mg} \cdot \mathrm{g}^{-1}\right)$, potassium (9 - $\left.27 \mathrm{mg} \cdot \mathrm{g}^{-1}\right)$ and sodium ( $7-36 \mathrm{mg} / \mathrm{g}$ ) compared to other parts. While comparatively higher $(p<0.05)$ concentration of carbon was measured in the stem (42\% - 45\%) and lowest (36\% - 43\%). was observed for roots (Figure 4).

Nitrogen, potassium, and carbon concentration in different parts of seedling showed significant $(p<0.05)$ negative correlation with salinity treatments. However, phosphorus in the bark, stems, and roots showed no significant $(p>$ $0.05)$ correlation with salinity except for leaves which showed a significant negative correlation with salinity treatments. Conversely, sodium concentration in plant parts showed significant $(p<0.05)$ positive correlation (Table 3$)$.

Table 2. Analysis of variance results for nitrogen, phosphorus, potassium, sodium and carbon concentration in seedling parts.

\begin{tabular}{ccccc}
\hline & Leaf & Bark & Stem & Root \\
\hline Nitrogen & $\mathrm{F}=6.20 ; p=0.0012$ & $\mathrm{~F}=2.55 ; p=0.0576$ & $\mathrm{~F}=2.61 ; p=0.0531$ & $\mathrm{~F}=5.45 ; p=0.0024$ \\
Phosphorus & $\mathrm{F}=9.57 ; p=0.0001$ & $\mathrm{~F}=4.04 ; p=0.0098$ & $\mathrm{~F}=11.84 ; p=0.0001 \mathrm{~F}=12.28 ; p=0.0001$ \\
Potassium & $\mathrm{F}=67.40 ; p=0.0001 \mathrm{~F}=55.86 ; p=0.0001 \mathrm{~F}=16.05 ; p=0.0001 \mathrm{~F}=221.30 ; p=0.0001$ \\
Sodium & $\mathrm{F}=67.25 ; p=0.0001 \mathrm{~F}=27.73 ; p=0.0001 \mathrm{~F}=70.62 ; p=0.0001 \mathrm{~F}=187.57 ; p=0.0001$ \\
Carbon & $\mathrm{F}=12.46 ; p=0.0001$ & $\mathrm{~F}=5.48 ; p=0.0023$ & $\mathrm{~F}=3.41 ; p=0.0200$ & $\mathrm{~F}=18.67 ; p=0.0001$ \\
\hline
\end{tabular}

Table 3. Correlation among salinity treatments and nitrogen, phosphorus, potassium, sodium and carbon in different parts of seedlings.

\begin{tabular}{ccccc}
\hline & Leaf & Bark & Stem & Root \\
\hline Nitrogen & -0.92 & -0.95 & -0.88 & -0.96 \\
Phosphorus & -0.94 & $-0.38^{*}$ & $-0.15^{*}$ & $-0.002^{*}$ \\
Potassium & -0.88 & -0.78 & -0.76 & -0.99 \\
Sodium & 0.90 & 0.94 & 0.98 & 0.97 \\
Carbon & -0.91 & -0.91 & -0.94 & -0.89 \\
\hline
\end{tabular}

${ }^{\star}$ Values are not significant at $95 \%$ confidence level. 


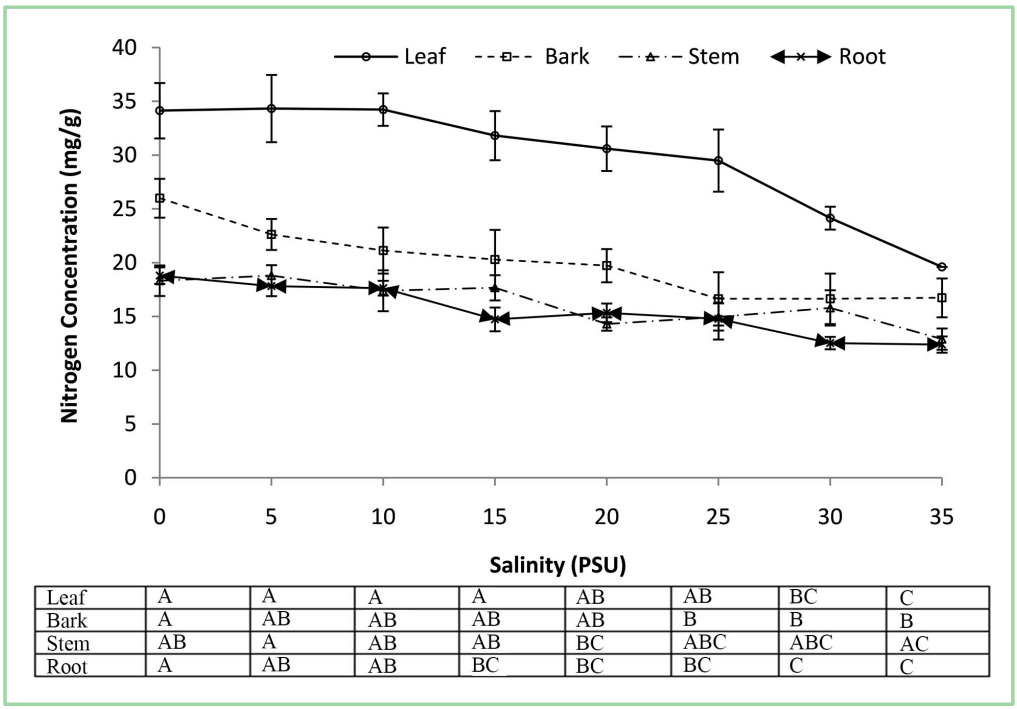

(a)

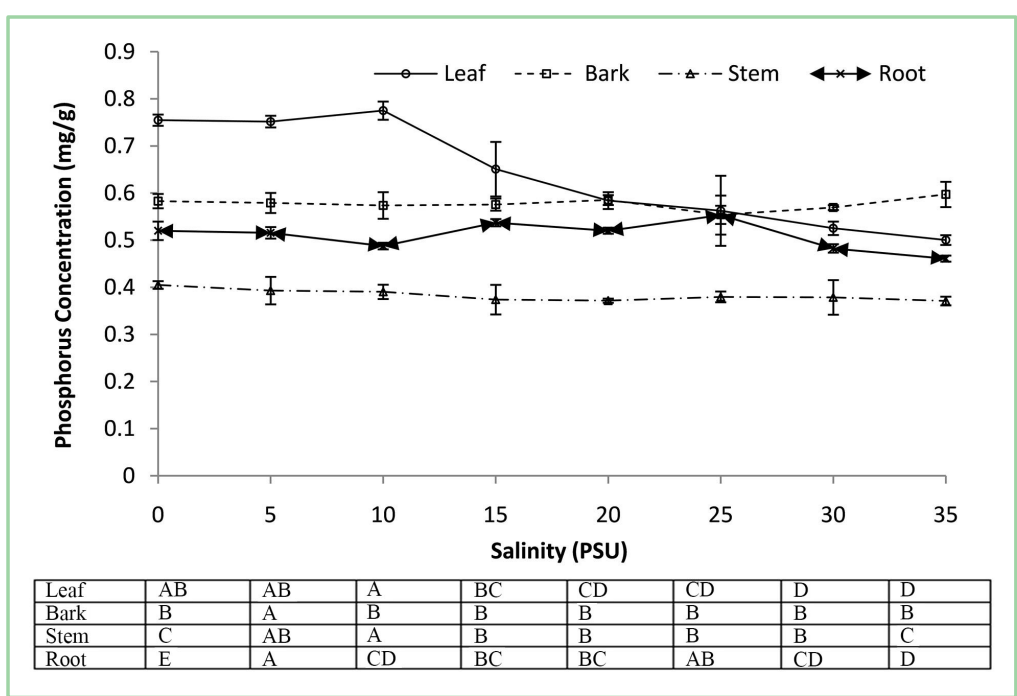

(b)

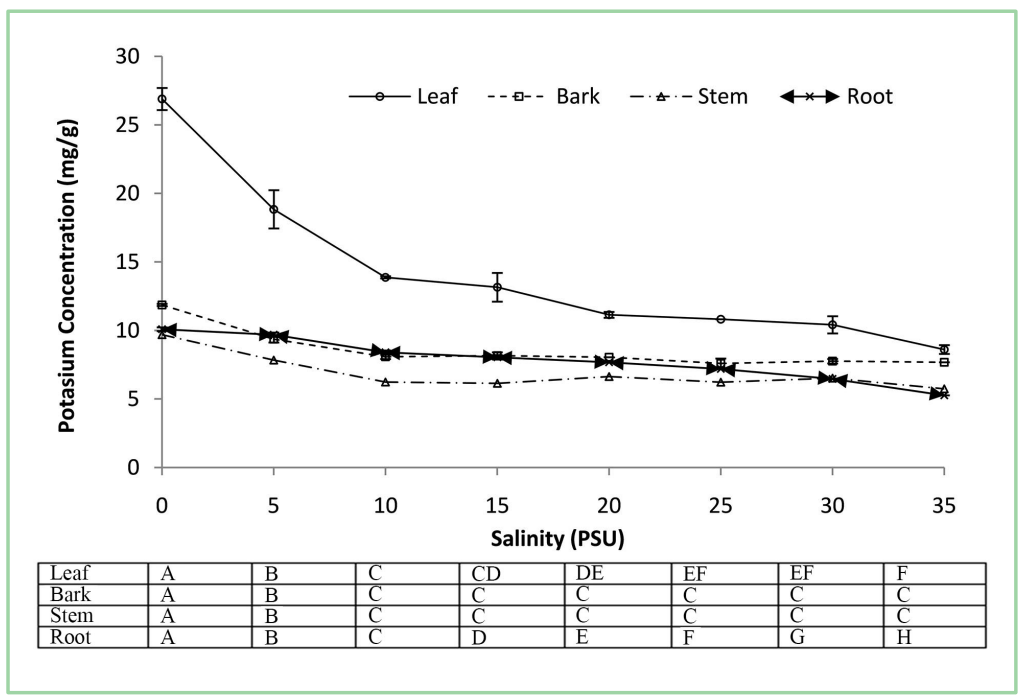

(c) 


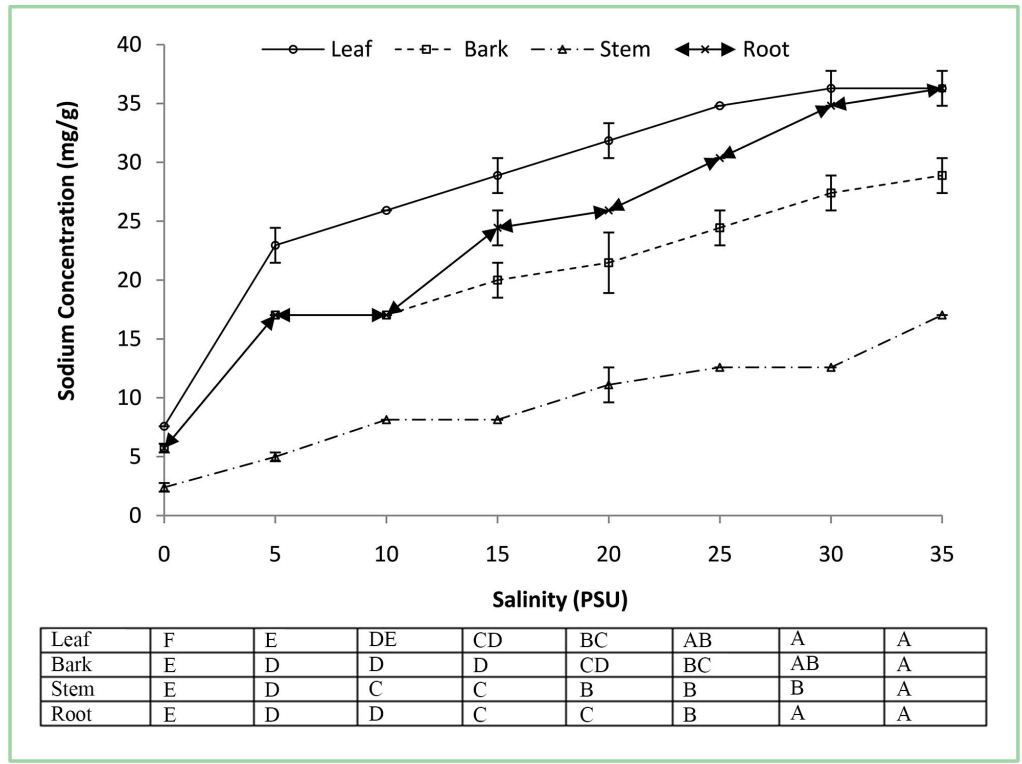

(d)

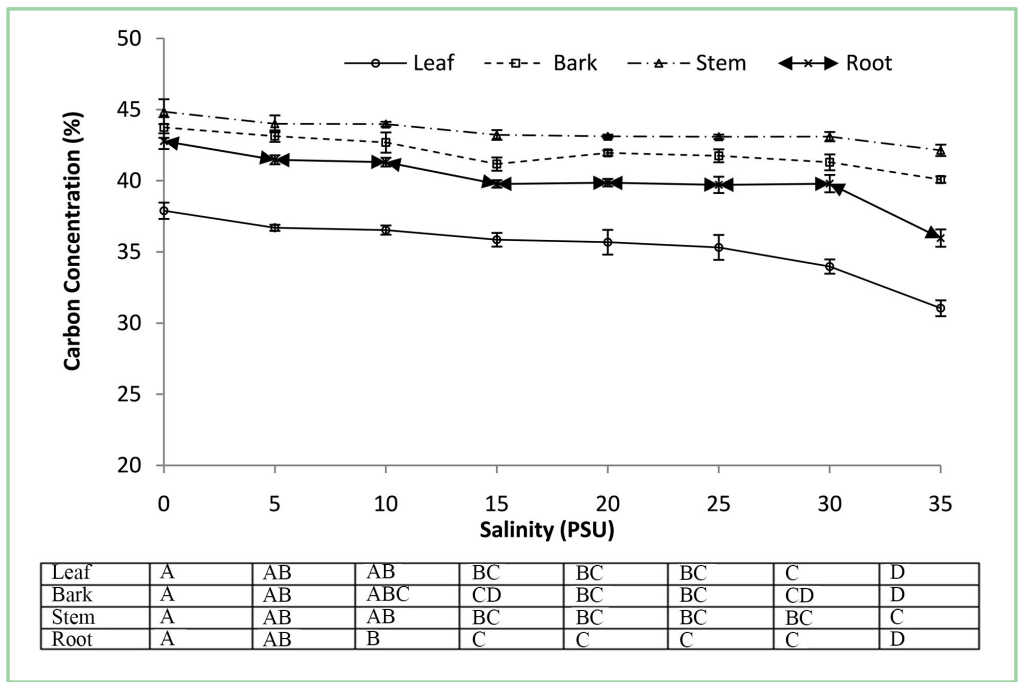

(e)

Figure 4. Concentration of (a) Nitrogen (b) Phosphorus (c) Potassium (d) Sodium, and (e) Carbon in different parts of seedling along with the salinity treatments. The table along with each figure showing the lettering of DMRT. The similar alphabet for each part of seedlings along the salinity treatments shows no significant $(p>0.05)$ difference at 95\% confidence level.

\section{Discussion}

Seedling survival of $X$. mekongensis was highest at non-saline to slightly saline condition. Survival and growth of mangrove seedlings largely are controlled by the salinity. The adaptive capacity to salinity of mangrove species is very much species-specific (Alam et al., 2017; Mahmood et al., 2014a; Nasrin et al., 2016). Mangrove plants engage most of their energy for survival at the high saline environment and conversely, a low saline environment facilitates the growth of mangroves (Lopez-Hoffman et al., 2006). This could be the reason to observe 
comparatively higher survival and growth of $X$. mekongesis seedlings at non-saline to low saline condition. Similar results were also reported with Ceriops australis and C. decandra at Australia (Ball, 2002); H. fomes (Mahmood et al., 2014a), X. granatum (Siddique et al., 2017), M. pinnata (Nasrin et al., 2016) in Bangladesh; A. germinans in Venezuela (Lopez-Hoffman et al., 2007). Ye et al. (2005) observed considerably higher RGR at 0 to 5 PSU salinity that decreased at higher salinity for three salt-secreting mangrove species, i.e. Acanthus ilicifolius, Aegiceras corniculatum and Avicennia marina. Higher salinity negatively influences the growth of mangrove seedlings (Smith, 1992) through limiting the water uptake (Clough, 1984) and causing low intercellular $\mathrm{CO}_{2}$ concentrations in leaves (Andrews \& Muller, 1985), decreased photosynthetic rates (Pezeshki et al., 1990; Sobrado, 1999). High salinity affects plant growth through sodium made toxicities or nutrient deficiencies or a combination of both (Khan et al., 2000; Läuchli \& Grattan, 2007).

Plant uptake nutrients from the soil and translocate to leaves, and synthesized food thereafter is distributed to different parts. The nutrient is an essential element for their growth and different physiological process of the plant (Jones et al., 1991; Marschner, 1995). Nutrients concentration not only varies from species to species but also varied among the parts of a plant and stages of growth (Jones et al., 1991; Mahmood et al., 2006). Nitrogen, phosphorus, and potassium are more abundant in physiologically active and photosynthetic tissue like leaves (Marschner, 1995). This could be the reason to observe the comparatively higher concentration of N, P and $\mathrm{K}$ concentration in leaves compared to other parts of seedlings. The higher amount of $\mathrm{K}$ in leaves suggests $\mathrm{K}$ as a principal element responsible for osmotic adjustment, which contributes to the salt regulation mechanism (Wei et al., 2003). Level of salinity does not affect necessarily the overall uptake of nitrogen by plants which may continue to accumulate nitrogen in the presence of excess salts despite a reduction in yield of dry mass (Silveira et al., 2001; Wahid et al., 2004). Nitrogen uptake in mangrove seedlings is not inhibitory by salinity (Kao et al., 2001). The final impact of salinity on the concentration of phosphorus in plants depends heavily on plant species, phase of ontogenesis, and level of salinity (Grattan \& Grieve, 1999). In most cases, the excess of salts in soil solution leads to a reduction in phosphorus concentration in the tissues of plants, but the results of some studies show that salinity may increase but that does not at least affect the uptake and accumulation of phosphorus (Kaya et al., 2001; Sonneveld \& de Kreij, 1999). The antagonistic relationship between sodium and potassium of this study suggested that sodium inhibited the uptake of potassium. Moreover, it is well documented that high concentrations of $\mathrm{Na}$ showed an antagonistic relationship with the uptake of $\mathrm{N}, \mathrm{P}$ and $\mathrm{K}$ and the extent of this relationship found to vary with species and plant parts (Cramer et al., 1991; Grattan \& Grieve, 1999). Salinity reduces the net photosynthesis (Pezeshki et al., 1990; Sobrado, 1999) and results in lower sequestration of carbon in plant parts. Similarly, the negative correlation values (Table 2) show the antagonistic relationship for salinity and carbon; and sodium and carbon in plant parts. 


\section{Conclusion}

Salinity has appeared as an important factor for regulating the survival and growth, nutrients, sodium, and carbon distributional pattern in different parts of $X$. mekongensis seedlings. Seedling survival at higher salinity was to some extend satisfactorily, but the relative growth rate was very low. A significant increase in sodium concentration and a decrease in nitrogen, potassium, and carbon concentration in seedling parts at higher salinities may be responsible for inhibiting the growth of seedling at the higher saline condition.

\section{Acknowledgements}

We are thankful to the United States Department of Agriculture (USDA) for their financial support; Ministry of Education and University Grants Commission, Bangladesh for their monitoring and smoothing the project activities. We also acknowledge the Sundarbans East Forest Division, and Forestry and Wood Technology Discipline, Khulna University and Centre for Integrated Studies on the Sundarbans (CISS), Khulna University for logistic support.

\section{Conflicts of Interest}

The authors declare no conflicts of interest regarding the publication of this paper.

\section{References}

Alam, M. R., Mahmood, H., Khushi, M. L. R., \& Rahman, N. M. (2017). Adaptive Phenotypic Plasticity of Avicennia officinalis L. along the Salinity Gradient in the Sundarbans of Bangladesh. Hydrobiologia, 808, 163-174. https://doi.org/10.1007/s10750-017-3420-Z

Allen, S. (1989). Chemical Analysis of Ecological Materials (2nd ed.). Oxford: Blackwells.

Andrews, T. J., \& Muller, G. J. (1985). Photosynthetic Gas Exchange of the Mangrove, Rhizophora stylosa Griff., in Its Natural Environment. Oecologia, 65, 449-455. https://doi.org/10.1007/BF00378922

Baethgen, W. E., \& Alley, M. M. (1989). A Manual Colorimetric Procedure for Measuring Ammonium Nitrogen in Soil and Plant Kjeldahl Digests. Communications in Soil Science and Plant Analysis, 20, 961-969. https://doi.org/10.1080/00103628909368129

Ball, M. C. (2002). Interactive Effects of Salinity and Irradiance on Growth: Implications for Mangrove Forest Structure along Salinity Gradients. Trees, 16, 126-139. https://doi.org/10.1007/s00468-002-0169-3

Chen, Y., \& Ye, Y. (2014). Effects of Salinity and Nutrient Addition on Mangrove Excoecaria agallocha. PLoS ONE, 9, e93337. https://doi.org/10.1371/journal.pone.0093337

Clough, B. F. (1984). Growth and Salt Balance of the Mangroves Avicennia marina (Forsk.). Vierh. and Rhizophora stylosa Griff. in Relation to Salinity. Australian Journal of Plant Physiology, 11, 419-430. https://doi.org/10.1071/PP9840419

Cramer, G. R., Epstein, E., \& Läuchli, A. (1991). Effects of Sodium, Potassium and Calcium on Salt-Stressed Barley. II. Elemental Analysis. Physiologia Plantaru, 81, 197-202. https://doi.org/10.1111/j.1399-3054.1991.tb02129.x

Downton, W. J. S. (1982). Growth and Osmotic Relations of the Mangrove Avicennia 
marina, as Influenced by Salinity. Australian Journal of Plant Physiology, 9, 519-528. https://doi.org/10.1071/PP9820519

Elumalai, D., \& Manikandan, T. (2013). Seedling Germination Changes by Sodium Chloride on Ceriops roxburghiana, Arnot. Halophyte. International Journal of Current Research and Review, 5, 89-94.

Fernández, N., Martinez, V., \& Carvajal, M. (2004). Effect of Salinity on Growth, Mineral Composition, and Water Relations of Grafted Tomato Plants. Journal of Plant Nutrition and Soil Science, 167, 616-622. https://doi.org/10.1002/jpln.200420416

Gopal, B., \& Chauhan, M. (2006). Biodiversity and Its Conservation in the Sundarbans Mangrove Ecosystem. Aquatic Sciences, 68, 338-354.

https://doi.org/10.1007/s00027-006-0868-8

Grattan, S., \& Grieve, C. (1999). Mineral Nutrient Acquisition and Response by Plants Grown in Saline Environments. In M. Pessarakli (Ed.), Handbook of Plant and Crop Stress (2nd ed., pp. 203-229). New York: Marcel Dekker. https://doi.org/10.1201/9780824746728.ch9

Hoppe-Speer, S. C., Adams, J. B., Rajkaran, A., \& Bailey, D. (2011). The Response of the Red Mangrove Rhizophora mucronata Lam. to Salinity and Inundation in South Africa. Aquatic Botany, 95, 71-76. https://doi.org/10.1016/j.aquabot.2011.03.006

Iftekhar, M. S., \& Saenger, P. (2008). Vegetation Dynamics in the Bangladesh Sundarbans Mangroves: A Review of Forest Inventories. Wetland Ecology and Management, 16, 291-312. https://doi.org/10.1007/s11273-007-9063-5

Jones, J. B., Wolf, Jr. B., \& Mills, H. A. (1991). Plant Analysis Handbook: A Practical Sampling, Preparation, Analysis and Interpretation Guide. New York: Micro-Macro Publishing.

Kao, W. Y., Tsai, H. C., \& Tsai, T. (2001). Effect of $\mathrm{NaCl}$ and Nitrogen Availability on Growth and Photosynthesis of Seedlings of a Mangrove Species, Kandelia candel (L.) Druce. Journal of Plant Physiology, 158, 841-846.

https://doi.org/10.1078/0176-1617-00248

Karimi, G., Ghorbanli, M., Heidari, H., Nejad, R. K., \& Assareh, M. H. (2005). The Effects of $\mathrm{NaCl}$ on Growth, Water Relations, Osmolytes and Ion Content in Kochia prostrata. Biologia Plantarum, 49, 301-304. https://doi.org/10.1007/s10535-005-1304-y

Kaya, C., Kirnak, H., \& Higgs, D. (2001). Enhancement of Growth and Normal Growth Parameters by Foliar Application of Potassium and Phosphorus in Tomato Cultivars Grown at High $(\mathrm{NaCl})$ Salinity. Journal of Plant Nutrition, 24, 357-367. https://doi.org/10.1081/PLN-100001394

Khan, M. A., Ungar, A., \& Showalter, A. M. (2000). Effects of Salinity on Growth, Water Relations and Ion Accumulation of the Subtropical Perennial Halophyte, Atriplex griffithii var. stocksii. Annals of Botany, 85, 225-232. https://doi.org/10.1006/anbo.1999.1022

Läuchli, A., \& Grattan, S. R. (2007). Plant Growth and Development under Salinity Stress. In Advances in Molecular Breeding toward Drought and Salt Tolerant Crops (pp. 1-32). Berlin: Springer.

Lopez-Hoffman, L., Aaten, N. P., Martinez-Romos, M., \& Ackerly, D. D. (2007). Salinity and Light Interactively Affect Neotropical Mangrove Seedlings at the Leaf and Whole Plant Levels. Oecologia, 150, 545-556. https://doi.org/10.1007/s00442-006-0563-4

Lopez-Hoffman, L., Denoyer, J. L., Monroe, I. E., Shaftel, R., Anten, N. P. R., Martinez-Ramos, M., \& Ackerly, D. D. (2006). Mangrove Seedling Net Photosynthesis, Growth, and Survivorship Are Interactively Affected by Salinity and Light. Biotropica, 
38, 606-616. https://doi.org/10.1111/j.1744-7429.2006.00189.x

Lovelock, C. E., Feller, I. C., Mckee, K. L., Engelbrechtb, M. J., \& Ball, M. C. (2004). The Effect of Nutrient Enrichment on Growth, Photosynthesis and Hydraulic Conductance of Dwarf Mangroves in Panama. Functional Ecology, 18, 25-33. https://doi.org/10.1046/j.0269-8463.2004.00805.x

Mahmood, H, Saha, S., Siddique, M. R. H., \& Hasan, N. M. (2014a). Salinity Stress on Growth, Nutrients and Carbon Distribution in Seedlings Parts of Heritiera fomes. International Journal of Environmental Engineering, 1, 71-77.

Mahmood, H. (2015). Handbook of Selected Plant and Species of the Sundarbans and the Embankment Ecosystem. Sustainable Development and Biodiversity Conservation in Coastal Protection Forests, Bangladesh (SDBC-Sundarbans). Dhaka: Project Implemented by the Deutsche Gesellschaftfür Internationale Zusammenarbeit (GIZ), GmbH on Behalf of the German Federal Ministry for Economic Cooperation and Development (BMZ).

Mahmood, H., Saberi, O., Misri, K., \& Japar, S. (2006). Seasonal Variation in Concentrations of N, P and K in Different Components of Bruguiera parviflora (Wight and Arnold) at Three Growth Stages in Malaysia. Indian Journal of Forestry, 29, 149-155.

Mahmood, H., Saha, S., Serajis, S., Siddique, M. R. H., \& Abdullah, S. M. R. (2014b). Salinity Influence on Germination of Four Important Mangrove Species of the Sundarbans, Bangladesh. Agriculture and Forestry, 60, 125-135.

Mahmood, H., Siddique, M. R. H., \& Saha, S. (2017). Threats on Biodiversity and the Possible Mitigation Measures for the Sundarbans Mangrove Forest, Bangladesh. In Conference: XIX Commonwealth Forestry Conference. Dehradun: Forest Research Institute.

Marschner, H. (1995). Mineral Nutrition of Higher Plants. New York: Academic Press.

Musyimi, D. M., Netondo, G. W., \& Ouma, G. (2007). Effects of Salinity on Gas Exchange and Nutrients Uptake in Avocados. Journal of Biological Sciences, 7, 496-505. https://doi.org/10.3923/jbs.2007.496.505

Naidoo, G. (2006). Factors Contributing to Dwarfing in the Mangrove Avicennia marina. Annals of Botany, 97, 1095-1101. https://doi.org/10.1093/aob/mcl064

Nandy, P., Das, S., Ghose, M., \& Spooner-Hart, R. (2007). Effects of Salinity on Photosynthesis, Leaf Anatomy, Ion Accumulation and Photosynthetic Nitrogen Use Efficiency in Five Indian Mangroves. Wetland Ecology and Management, 15, 347-357. https://doi.org/10.1007/s11273-007-9036-8

Nasrin, S., Mahmood, H., Abdullah, S. M. R., Alam, M. R., Saha, S., \& Siddique, M. R. H. (2016). Salinity Influence on Survival, Growth and Nutrient Distribution in Different Parts of Millettia pinnata (L.) Panigrahi Seedlings. Agriculture and Forestry, 62, 161-173. https://doi.org/10.17707/AgricultForest.62.4.19

Navarro, A., Bañón, S., Conejero, W., \& Sánchez-Blanco, M. J. (2008). Ornamental Characters, Ion Accumulation and Water Status in Arbutus unedo Seedlings Irrigated with Saline Water and Subsequent Relief and Transplanting. Environmental and Experimental Botany, 62, 364-370. https://doi.org/10.1016/j.envexpbot.2007.10.010

Olsen, S. R., \& Sommers, L. E. (1982). Phosphorus. In A. L. Page (Ed.), Methods of Soil Analysis Part 2 Chemical and Microbiological Properties (pp. 403-430). Madison, WI: American Society of Agronomy, Soil Science Society of America.

Patel, N. T., Gupta, A., \& Pandey, A. N. (2010). Strong Positive Growth Responses to Salinity by Ceriops tagal, a Commonly Occurring Mangrove of the Gujarat Coast of India. AoB Plants, 2010, plq011. https://doi.org/10.1093/aobpla/plq011 
Pezeshki, S. R., Delaune, R. D., \& Ratrick, W. H. P. (1990). Differential Response of Selected Mangroves to Soil Flooding and Salinity: Gas Exchange and Biomass Partitioning. Canadian Journal of Forest Research, 20, 869-874. https://doi.org/10.1139/x90-116

Siddiqi, N. A. (2001). Mangrove Forestry in Bangladesh. Chittagong: Institute of Forestry \& Environmental Science, University of Chittagong.

Siddique, M. R. H., Saha, S., Serajis, S., \& Mahmood, H. (2017). Salinity Strongly Drives the Survival, Growth, Leaf Demography, Nutrients Partitioning in Seedlings Parts of Xylocarpus granatum J. Koenig. iForest-Biogeosciences and Forestry, 10, 851-856. https://doi.org/10.3832/ifor2382-010

Silveira, J. A. G., Melo, A. R. B., Viégas, R. A., \& Oliveira, J. T. A. (2001). Salinity-Induced Effects on Nitrogen Assimilation Related to Growth in Cowpea Plants. Environmental and Experimental Botany, 46, 171-179. https://doi.org/10.1016/S0098-8472(01)00095-8

Smith, S. M., \& Snedakar, S. C. (1995). Salinity Responses in Two Populations of Viviparous Rhizophora mangle L. Seedlings. Biotropica, 27, 435-440. https://doi.org/10.2307/2388955

Smith, T. J. (1992). Forest Structure. In A. I. Robertson, \& D. M. Alongi (Eds.), Tropical Mangrove Ecosystems (101-136).Washington DC: American Geophysical Union.

Sobrado, M. A. (1999). Leaf Photosynthesis of the Mangrove Avcicennia germinans as Affected by NaCl. Photosynthetica, 36, 547-555. https://doi.org/10.1023/A:1007092004582

Sonneveld, C., \& de Kreij, C. (1999). Response of Cucumber (Cucumis sativus L.) to an Unequal Distribution of Salt in the Root Environment. Plant Soil, 209, 47-56. https://doi.org/10.1023/A:1004563102358

Tuna, A. L., Kaya, C., Ashrak, M., Altunlu, H., Yokas, I., \& Yagmur, B. (2007). The Effects of Calcium Sulphate on Growth, Membrane Stability and Nutrient Uptake of Tomato Plants Grown under Salt Stress. Environmental and Experimental Botany, 59, 173-178. https://doi.org/10.1016/j.envexpbot.2005.12.007

Wahid, A., Hameed, M., \& Rasul, E. (2004). Salt-Induced Injury Symptom, Changes in Nutrient and Pigment Composition and Yield Characteristics of Mung Bean. International Journal of Agriculture and Biology, 6, 1143-1152.

Wei, W., Bilsborrow, P. E., Hooley, P., Fincham, D. A., Lombi, E., \& Forster, B. P. (2003). Salinity Induced Differences in Growth, Ion Distribution and Partitioning in Barley between the Cultivar Maythorpe and Its Derived Mutant Golden Promise. Plant Soil, 250, 183-191. https://doi.org/10.1023/A:1022832107999

Ye, Y., Tam, N. F. Y., Lu, C. Y., \& Wong, Y. S. (2005). Effects of Salinity on Germination, Seedling Growth and Physiology of Three Salt-Secreting Mangrove Species. Aquatic Botany, 83, 193-205. https://doi.org/10.1016/j.aquabot.2005.06.006 